\title{
ARTYKUŁY
}

PIOTR LEŚNIAK

\section{STAWANIE SIĘ OSOBĄ JAKO PROCES}

\begin{abstract}
Streszczenie: Pierwsze trzy części mają charakter wstępny. Ich zadaniem jest, na podstawie filozofii procesu Whiteheada, zdefiniować podstawowe terminy, takie jak cielesność, osoba ludzka, świadomość, jedność osobowa, etapy, fazy i wymiary procesu stawania się osobą. Szczególnie istotne dla rozumienia pojęcia osoby ludzkiej okazuje się właściwe rozumienie pojęcia Boga. Wskazano różnice pomiędzy Platońską i Arystotelesowską teologią oraz psychologią, szczególnie w aspekcie duszy pożądliwej. W kolejnych częściach omówione są etapy stawania się osobą ludzką: dzieciństwo, dorosłość i dojrzałość. Każdy z nich przedstawiony zostaje z perspektywy łączącej wymiar cielesny z duchowością. W ostatnim rozdziale podjęto próbę wysłowienia niektórych Platońskich intuicji psychologicznych w języku współczesnym. Przede wszystkim zrekonstruowano Platoński opis stawania się osobą dojrzałą poprzez rozwój duchowo-psychologiczny opisany w Państwie. Prowadzi to do ukazania Platonizmu jako podstawy nowoczesnej praktyki terapeutycznej.
\end{abstract}

Słowa kluczowe: osoba, rozwój, proces, stawanie się, psychologia Platona

1. Wstęp. 2. Osoba ludzka i jej ciało. 3. Etapy, wymiary i fazy stawania się osobą ludzką. 4. Jedność osoby. Bóg jako jedna osoba i jako jedność osób. 5. Etapy życia ludzkiego. Dzieciństwo. 6. Wchodzenie w dorosłość. Budowanie samodzielności. 7. Dojrzała osoba ludzka. 8. Uczucia duchowe i emocje ciała. Nieświadome wymiary osoby ludzkiej w ujęciu Platona. 9. Podsumowanie.

\section{WSTĘP}

Wśród pytań filozoficznych trudno wskazać bardziej fundamentalne i ważne pytanie, niż to o osobę ludzką, jej sposób istnienia, kierunek rozwoju i przeznaczenie. Tekst jest próbą odpowiedzi na to pytanie w oparciu o teksty Platona, filozofię procesu Alfreda Whiteheada oraz inspiracje płynące ze współczesnego, tzw. ucieleśnionego podejścia w psychologii poznawczej. Być może nie bez wpływu na treść zaproponowanych odpowiedzi pozostaje fakt, że autor stawia sobie 
to pytanie jako wierzacy chrześcijanin, jednak tekst nie ma żadnych intencji apologetycznych. Metodą czytania Platona przyjętą w tym tekście jest uznanie jego dialogów, zgodnie z sugestią Pierra Hadota, za zapis pewnej praktyki duchowo-terapeutycznej i interpretowanie sensu jego doktryny w świetle współczesnej praktyki coachingu, doradztwa i terapii filozoficznej. Filozofia procesu z kolei jest traktowana, zgodnie z zaproszeniem samego Whiteheada jako zespół pojęć i intuicji „do twórczego rozwijania” w konkretnych zastosowaniach.

Żyjemy w czasach, w których pojawia się paląca potrzeba filozofii praktycznej w platońskim rozumieniu. Społeczeństwa Zachodu przeżywają współcześnie „epidemię” różnego typu zaburzeń procesu stawania osobą ludzką. Dotyczy to zarówno dzieci, młodzieży jak i osób dorosłych. Najczęściej diagnozowana wśród zaburzeń rozwojowych jest nadpobudliwość psychoruchowa (ADHD) oraz zaburzenia w rozwoju komunikacji i nawiązywania relacji społecznych zaliczane do szeroko rozumianego spektrum autyzmu. Wśród dorosłych zaburzenia w rozwoju kompetencji społecznych przejawiają się najwyraźniej we wzroście liczby osób niezdolnych do podejmowania długotrwałych zobowiązań - osób, które nie potrafią budować trwałych i satysfakcjonujących związków z innymi ludźmi, niezdolnych do głębokiego rozumienia intencji innych osób oraz brania odpowiedzialności. Diagnoza źródeł tych procesów i refleksja nad sposobami zapobiegania im w przyszłości wymaga nie tylko wąsko specjalistycznych analiz socjologicznych, psychologicznych czy kognitywistycznych, ale też syntez filozoficznych nawiązujących stylem do sposobu uprawiania filozofii w starożytności.

\section{OSOBA LUDZKA I JEJ CIAŁO}

Należy przede wszystkim odróżniać osobę ludzką od bytu fizycznego konkretnego człowieka - jego ciała, pojmowanego jako obiekt fizyczny w czasoprzestrzeni, ale te $\dot{z}$, co istotne, od ciała czującego, pojmowanego jako podmiot procesów biologicznych. Ciało ludzkie 
tylko w tym pierwszym znaczeniu jest badanym narzędziami nauk przyrodniczych „przedmiotem fizycznym”. Osoba istnieje w czasie inaczej nie tylko niż przedmioty materialne, ale też inaczej niż podmioty biologiczne. Poważnym błędem jest nie tylko odrzucanie istnienia osobowego centrum człowieka (Platońskie pojęcie duszy nieśmiertelnej), ale też pojmowanie osoby jako podmiotu czysto racjonalnego z pominięciem jej podmiotowości biologicznej (Platońskiej duszy śmiertelnej). Błąd ten ma długi rodowód. Wywodzi się od Kartezjusza (choć, jak to zostanie dalej uzasadnione, jego początki sięgają Arystotelesa) wzmocniony zostaje autorytetem Kanta i utrwalony przez podział nauk na humanistyczne i przyrodnicze, wzdłuż linii inspirowanej kartezjanizmem. Ten sposób myślenia ma swoje uzasadnienie w metodologicznej różnicy pomiędzy naukami przyrodniczymi a humanistycznymi, stoi jednak w sprzeczności z żywą duchowo-cielesną rzeczywistością osoby ludzkiej.

Idea stawania się osobą w przedstawionym tu ujęciu procesowym zakłada odrębność bytową sfery osobowej oraz biologicznej a zarazem ich powiązanie w procesie dorastania i dojrzewania człowieka oraz $\mathrm{w}$ „mikroprocesach” składających się na każdą z "kropel naszego doświadczenia”. Osoba duchowa, o której mówimy w tym tekście, nie jest tajemniczym homunculusem ukrytym gdzieś w ciele fizycznym, lecz żywym człowiekiem - uczestnikiem rzeczywistości społecznej, podejmującym wybory, decyzje i zobowiązania, przeżywającym emocje i uczucia, doświadczającym narodzin, dorastania, dojrzewania i umierania. Znamienne jest to, że pojęcie osoby jako „istoty duchowej” zostaje w tym tekście dookreślone na drodze prowadzącej przez zagadnienie ludzkiej cielesności, która w świetle współczesnych badań okazuje się czymś bardzo odległym od mechanistycznej wizji Kartezjusza. Dopiero odsłonięcie rzeczywistości ciała ludzkiego jako ciała własnego (la chair Maurice’a Merleau-Ponty'ego) albo ciała żywego (der Leib u Edyty Stein) czy mówiąc językiem Platona duszy afektywnej (epithymetikon) pozwala ukazać we właściwym świetle rzeczywistość ludzkiego ducha. 
Osoba ludzka istnieje w dwu rzeczywistościach. Jako osoby obdarzone racjonalnością (dusze rozumne) należymy do obszaru bytowego, który Platon określał terminem aion $i$ wiązał $\mathrm{z}$ nieustająca stwórczą aktywnością Boga. Jako czujące, żywe organizmy istniejemy w czasie chronos - podlegamy rytmom przyrody, do której należą nasze ciała wraz z ich śmiertelną duszą stwarzaną według Platona przez pochodzących od Stwórcy bogów. Można powiedzieć, że człowiek jako osoba istnieje $\mathrm{w}$ dwu wymiarach czasu: $\mathrm{w}$ odmierzanym przez zegary czasie fizycznym oraz w samym rdzeniu swojej istoty $\mathrm{w}$ niefizycznym trwaniu. Stawanie się tą konkretną osobą ludzką, którą teraz jestem, jest składnikiem procesu stwarzania, który dokonuje się poprzez nieustanne wkraczanie w czas fizyczny wiecznego Teraz Boga. Człowiek stający się osobą uczestniczy w procesie, który Platon opisuje jako „nakłanianie konieczności” (czyli tego, w obszarze naszego doświadczenia, co przejawia się na poziomie odczuwania ciała jako stały napływ nasyconych emocjonalnie treści), aby „posłuchała mądrych rad rozumu"1. Dla przykładu, stajemy się matką lub ojcem w znaczeniu osobowym nie poprzez to, co wymusza na nas niejako konieczność biologicznych, naturalnych procesów, ale poprzez dobrowolną motywację świadomego i trwałego uczestniczenia w relacji osobowej z dzieckiem. Proces „stawania się rodzicem” jest dobrą ilustracją tego niezwykłego splotu - trwania w relacjach osobowych, pomimo nieustannych przemian fizycznych i emocjonalnych, jakim podlega jednostka ludzka. Dojrzałość płciowa jest warunkiem koniecznym fizycznego macierzyństwa, jednak do macierzyństwa i ojcostwa jako relacji duchowej istoty ludzkie dojrzewają nie poprzez biologiczne procesy rozwoju układu rozrodczego, ale poprzez umiejętność uświadamiania sobie relacji osobowych, co wyraża się między

1 „W rzeczy samej pochodzenie tego świata jest mieszane: powstał on dzięki połączeniu konieczności (ananke) z rozumem (noos). Rozum jednak (...) ją przekonał, aby skierowała do dobrego, (...) rzeczy, które powstawały. W ten sposób pod wpływem konieczności, która się dała przekonać mądrym radom, powstał ten świat na początku". Platon, Timajos Kritias albo Atlantyk, tłum. z gr. P. Siwek, Warszawa 1986, 60, (48a). 
innymi w gotowości przyjęcia określonych zobowiązań. Macierzyństwo i ojcostwo w sensie osobowym nie jest jednak wynikiem jakiegoś jednorazowego zobowiązania prawnego czy moralnego, lecz polega na zdolności do (mniej lub bardziej świadomego) uczestniczenia $\mathrm{w}$ procesie stwarzania, co ostatecznie oznacza uczestniczenie w pozaczasowej relacji jaka zachodzi pomiędzy osobami (hipostasis) Bożymi. Znaczenie używanych tu terminów „Bóg” oraz „osoba ludzka”, stanie się jaśniejsze, gdy przyjrzymy się analogii, jaka zachodzi pomiędzy Platońskim opisem duszy (jednej w trzech ośrodkach) a trzema rodzajami Jednego Bytu odwiecznie istniejącego.

Celem tekstu jest opis procesu stawania się osobą, który łączy cielesne i duchowe aspekty rozwoju człowieka. Opisane niżej fazy stawania się osobą ludzką ukazują bycie człowiekiem jako proces, w którym od początku osoba duchowa wspólistnieje z dokonującymi się w czasie przyrody przemianami ciała.

\section{ETAPY, WYMIARY I FAZY STAWANIA SIĘ OSOBĄ LUDZKĄ}

Pojęcie etapu należy przede wszystkim odróżnić od pojęcia fazy. Etapy to fragmenty horyzontalnego wymiaru procesu rozwoju osoby ludzkiej. Jest to dokonujący się w czasie fizycznym, od narodzin do śmierci, proces w zwykłym rozumieniu - polegający na przechodzeniu od zdarzeń początkowych (narodziny) poprzez pośrednie: dzieciństwo, dorastanie i dojrzewanie, do zdarzeń końcowych (śmierć). W kolejnych etapach następują zmiany obserwowalnych własności i przymiotów jednostki ludzkiej pojmowanej jako ciąg zobiektywizowanych zdarzeń. $Z$ kolei fazy to elementy strukturalne tak zwanego „procesu wertykalnego”, który nie jest sekwencją zdarzeń w czasie, może być doświadczony jedynie subiektywnie, i który w ludzkim doświadczeniu przejawia się jako nieustające rodzenie się kolejnych chwil w obszarze wiecznego Teraz. Zgodnie z założeniami metafizyki Whiteheada nie należy pojmować faz wewnętrznego „zrastania się" (concrescence) jednostkowych zajść jako następujących po sobie 
etapów, ale jako elementy strukturalne bezczasowego trwania 2 . Platon, opisując ten proces wiecznego stawania się (wkraczania w czas tego, co pozaczasowe), wskazuje jego trzy aspekty; „to, co się rodzi (gignomenon); to, w czym się ono rodzi (chora)" oraz to "na czyje podobieństwo formuje się to, co zrodzone" i aby umożliwić słuchaczom zrozumienie tej wysoce abstrakcyjnej idei, Platon używa metafory ludzkiej rodziny: „można porównać do matki, ten czynnik, który przyjmuje, do ojca czynnik, od którego ona przyjmuje; do dziecka zaś naturę pośrednią"

Od strony subiektywnej stawanie się osobą można opisać jako proces uświadamiania sobie wartości osobowych albo proces dojrzewania do świadomego „przyjmowania” uczuć osobowych. Wyrażenie „przyjmowanie uczuć" opisuje stan psychiczny, który od strony obiektywnej można ująć jako gotowość zaangażowania się osoby w określone wartości lub - bardziej zgodnie z duchem antyku otwarcie się na oddziaływanie określonych wzorców osobowych (sprawiedliwy - dikaios to ten należący do bogini Dike). Zgodnie z przyjętą tu ontologią, wartości osobowe nie są abstraktami, lecz cechami osób duchowych, które można pojąć jako ponadczasowe wzorce, w momencie zaangażowania się jednostki stającymi się $\mathrm{w}$ jej indywidualnym doświadczeniu uczuciami - emocjonalną siłą (dynamis) wpływającą na sposób działania. Słowa „emocja” używam tu najczęściej w węższym znaczeniu, odnosząc je do emocji pierwotnych związanych ściśle z reakcjami ciała (strach, złość, ból, rozkosz zmysłowa, odraza) i używając zamiennie z terminem „afekt”, natomiast określenie „uczucie”, w szczególności uczucie duchowe, odnosi się do złożonych reakcji emocjonalnych o silnym komponencie

2 Whitehead używa do opisu wertykalnego wymiaru określenia „proces mikroskopowy” (microscopic process), aby zwrócić uwagę na bardziej fundamentalny i nieobserwowalny charakter tego wymiaru stawania się, albo wyrażenia „konkrescencja” (concrescence), aby zwrócić uwagę na unifikujący (wiązanie wielości w jedno) charakter tego wymiaru. Por. J.B. Cobb, Jr., Słownik pojęć Whiteheada, tłum. z ang. Ł. Lamża, Kraków 2016, 145-147.

3 Platon, Timajos, dz. cyt., 64. 
intelektualnym i uwarunkowanych kulturowo. Najszerszy zakres (najuboższą treść) ma słowo „czucie”, którego używam w technicznym Whiteheadowskim znaczeniu (jako feeling): do każdego zaistnienia w jego konkretności i subiektywności (każde zaistnienie posiada „wnętrze”, jest więc rodzajem czucia). Z kolei słowa „uświadamianie” $\mathrm{i}$,świadomy” używam w dwu znaczeniach. W pierwszym, węższym, jako opartej na kompetencjach językowych zdolności odnoszenia się do treści własnych przeżyć, co skutkuje umiejętnością samookreślania czy autodeterminacji (samoświadomość). Tak rozumiana świadomość nie jest warunkiem koniecznym posiadania doświadczeń osobowych, wymaga ona istnienia ukształtowanej struktury egotycznej i nie pojawia się w okresie wczesnego dzieciństwa. Świadomość w drugim, szerszym znaczeniu (jako podmiotowość powiązana z emocjonalnością i kreatywnością) jest cechą osoby ludzkiej już od urodzenia, podczas gdy rozwój tej drugiej rozpoczyna się dopiero wraz pojawieniem się poczucia odrębności fizycznej własnej osoby, zdolnością tworzenia własnych narracji, pamięcią autobiograficzną i zdolnością wnioskowania o nieobserwowalnych stanach rzeczy takich jak przekonania innych ludzi, tj. po utworzeniu się znanej nam z życia dorosłego struktury egotycznej (około 3-4 roku życia).

Mówienie o trwaniu w relacjach osobowych nawiązuje do używanego przez Kazimierza Dąbrowskiego pojęcia wertykalnego wymiaru (podobne intuicje pojawiają się też u Carla Rogersa) rozwoju człowieka. Według Dąbrowskiego nie można interpretować zachowań człowieka jednowymiarowo. Potrzebne jest uwzględnienie wymiaru wartości moralnych i rozwoju moralnego, który może przebiegać w innym kierunku niż rozwój sprawności biologicznej organizmu. Czasem rozwój osobowy człowieka prowadzi przez okresy cierpienia i dezorganizacji psychofizycznej. Rozwój moralny wymaga porzucenia sposobu bycia opartego na motywacji wyłącznie egocentrycznej. Dokonuje się to często w procesach dezintegracji (dezintegracja pozytywna), rozbicia wewnętrznego, poczucia smutku i niskiej samooceny. Traktowanie tych zjawisk w czysto medyczny sposób jako zaburzeń 
wymagających jedynie usunięcia, według Dąbrowskiego, przynieść może więcej szkody niż pożytku. Procesy te stają się zrozumiałe jako składniki rozwoju osobowego dopiero po umieszczeniu ich w dłuższej perspektywie czasowej i rozpoznaniu ich jako środków do celu, jakim jest dojrzałość osobowa.

Odróżnienie wertykalnego i horyzontalnego wymiaru procesu stawania się osobą ma swój odpowiednik w Whiteheadowskim odróżnieniu genetycznego i współrzędnego (genetic and coordinate) podziału zaistnień aktualnych. Proces w aspekcie genetycznym Whitehead nazywa zrastaniem się lub konkretyzacją (concrescence), z kolei wymiar współrzędny procesu stawania się to wymiar relacji czasowych i przestrzennych pomiędzy ukonkretnionymi już (gotowymi) doświadczeniami. Jest on nam dany w doświadczeniu codziennym jako sekwencje czasowe (diachroniczne) zdarzeń oraz ich układy synchroniczne (przestrzenne). Stąd w naszym doświadczeniu potocznym przekonanie, że istniejemy $\mathrm{w}$ gotowej przestrzeni i czasie. $Z$ tego samego źródła pochodzi ogromna rola narracji (uporządkowanych diachronicznie zespołów zdarzeń) w konstytuowaniu się naszego poczucia tożsamości osobowej. Jednak to, co metafizycznie ugruntowuje nasze doświadczenie tożsamości osobowej, jest zgodnie z metafizyką Whiteheada cechą procesu wertykalnego - jest to, dokonujące się poza naszą świadomością, ujmowanie w jedno wielości różnego typu czuć. Nasze ludzkie „zaistnienia”, które odczuwamy od wewnątrz jako kolejne chwile naszego bycia w świecie, są częścią ogromnego procesu, który jest obejmującym cały Wszechświat niekończącym się „Zwielokrotnianiem” oraz „integrowaniem” wielości w jedno.

Fazy każdego kolejnego zaistnienia to jego elementy strukturalne dające się wyróżnić we wszystkim, co istnieje aktualnie. Dotyczy to zarówno, kwantów energii w odległych galaktykach, doznań prostych organizmów jak i doświadczeń osób duchowych. Whitehead przyjmuje istnienie trzech faz konkrescencji: fazy inicjalnej (initial) albo konformalnej (conformal), fazy dopełniającej (supplementary) oraz fazy spełnienia (satisfaction). Funkcją fazy konformalnej jest przyjmowanie 
i odtwarzanie przeszłości, jest to ta funkcja procesów kwantowych, dzięki której świat fizyczny posiada swoją stabilność i regularność. Jej odpowiednikiem w dziedzinie psychicznej jest zarażenie emocjonalne. Faza dopełniająca to faza, której funkcją jest uwypuklenie „swoistości” nowego zaistnienia. Pojawia się tu element pozytywnego lub negatywnego wartościowania. Każde kwantowe wzbudzenie energii ma według Whiteheada pewien element swobody - ma naturę „wibracyjną”. W dziedzinie psychicznej odpowiednikiem tego jest możliwość zmiany podmiotowej formy odczuwania. Przejęta od kogoś emocja może, stając się częścią mojego świata, zmienić swój charakter np. - używając przykładu Johna Cobba - zadowolenie z czyjejś porażki może się $\mathrm{w}$ moim przeżywaniu zamienić we współczucie. Z kolei, główną funkcją spełnienia jest wpływanie na kolejne zaistnienia. Jest to ten wymiar trwania, który przejawia się w aktywności „formującej” inne zaistnienia.

Zakładam, że kolejne etapy życia człowieka (dzieciństwo, dorosłość, dojrzałość) można powiązać z fazami w ten sposób, że każdy z etapów uwypukla cechy określonej fazy procesu wertykalnego. Dzieciństwo (w szczególności to wczesne) akcentuje fazę inicjalną zaistnienia, dorosłość fazę dopełniającą, a dojrzałość fazę spełnienia. Każda chwila naszego ludzkiego życia jest w tym sensie obrazem jego całości. Można to też zinterpretować po Platońsku, traktując etapy jako poziomy rozwoju miłości albo przypisując etapom odpowiednie rodzaje dusz i odpowiadające im cnoty (dzieciństwu umiarkowanie, dorosłości męstwo, a dojrzałości roztropność), albo najogólniej: wskazując, że na każdym z etapów przejawia się najsilniej jeden z rodzajów Bytu: „Macierz” (chora) w okresie dzieciństwa, drugi rodzaj czyli „To, co powstaje” w okresie dorastania i pierwszy rodzaj, czyli „Ten, który odwiecznie istnieje" (Byt prawdziwy) na etapie dojrzałości. Intuicje te nabiorą większej precyzji w dalszej części artykułu. 


\section{JEDNOŚĆ OSOBY. BÓG JAKO JEDNA OSOBA I JAKO JEDNOŚĆ OSÓB}

Pojęcie osoby, jakim posługuje się Whitehead, wymaga pewnego uzupełnienia. Początkowo używa on pojęcia „społeczność (sekwencja) osobowa” dla opisania ciągów zaistnień cechujących się pewną wspólną formą. W tym znaczeniu nie tylko organizmy żywe, ale nawet poszczególne zdarzenia $\mathrm{z}$ historii elektronu należałoby uznać za przejawy porządku osobowego. Następnie określa osobę jako sekwencję „końcowych zaistnień doświadczających” (final percipient occasion), których egzemplifikacją są proste doświadczenia zmysłowe ssaków. W ciągu zdarzeń o charakterze fizycznym w układzie nerwowym sekwencje osobowe pojawiają się jako ich „zwieńczenie”. Whitehead nazywa je „osobą żyjącą”. Osoba w tym znaczeniu jest już zdolna do uczenia się, jednak nadal takie pojęcie osoby nie pozwala wyjaśnić, na czym polega wchodzenie w dojrzałe relacje osobowe.

Stajemy się osobami dzięki bliskim nam ludziom - uczestnicząc w relacjach osobowych - biorąc (w większości odbywa się to niezależnie od naszych w pełni świadomych doświadczeń) od wychowawców, korzystając na swój sposób, a następnie przekazując ten „dar emocjonalno-kulturowy” naszym wychowankom. Pomijając w tym procesie szczegóły i pozostawiając jedynie samą strukturę: przejmowanie-modyfikowanie-przekazywanie, jest to najogólniejsza postać każdego zaistnienia, w tym Boga. Bóg w systemie Whiteheada nie jest wyjątkiem od reguł, lecz ma być najpełniejszą egzemplifikacją zasad metafizycznych. Gdzie jednak w Whiteheadowskim pojęciu Boga jego indywidualność i tożsamość osobowa? Głównym przedmiotem zainteresowania Whiteheada, który filozofią Boga zajmuje się zdaje się w efekcie badań nad filozofią przyrodoznawstwa, pozostaje kosmologia (książka Process nad Reality nosi podtytuł An essay in cosmology). Stąd, być może, akcentowanie w pojęciu Boga jego niezmiennej natury Pierwotnej (Primordial), która jest ontycznym fundamentem praw przyrody oraz natury Następczej (Consequent), która wyraża fakt uczestniczenia Boga w świecie. Bóg Whiteheada 
nie jest „imperialnym władcą”, lecz zgodnie z intuicją chrześcijańską współcierpi z człowiekiem, w swej naturze Następczej, będąc jednocześnie nośnikiem ideałów i niezmiennych wzorców. Whiteheadowski Bóg, pomimo podziwu, jaki myśliciel ten wyraża wobec Platona, bardziej jednak przypomina Boga Arystotelesa - jest jedynie przyczyną celową świata, nie ma mocy sprawczej - jest przedmiotem podziwu, wabi zaistnienia aktualne w stronę swojego Piękna. Tym, co w systemie Whiteheada jest dynamicznym źródłem odwiecznego powstawania, nie jest Bóg, lecz kreatywność (creativity), traktowana jako zasada pierwotna i niedefiniowalna, porównywana przez Whiteheada do Arystotelesowskiej materii pierwszej. Jednak już starożytni (Plotyn) zauważyli, że Arystotelesowska teologia nie należy do jego największych osiągnięć. Platońska wizja „Boga w trzech przejawach", który odwiecznie stwarza świat i nie potrzebuje do tego niczego (sic! - język polski ze swoją nielogicznością pozwala wyrazić tę nieortodoksyjną, ale zaskakująco głęboką myśl), wydaje się intuicjom chrześcijańskim dużo bliższa niż Arystotelesowska. Należy jednak odrzucić stereotypowe interpretacje. Przede wszystkim należy podkreślić, że Platoński Bóg-Stwórca nie jest rzemieślnikiem w dosłownym sensie, który potrzebuje „materiału”, aby inicjować proces stworzenia i który winą za obecny stan swojego dzieła może obarczyć niedoskonałość budulca. Bóg-Stwórca jest personifikowany w opisie Platona podobnie jak wszystkie byty w obszarze Platońskiego Nieba, nie jest też jakąś kosmiczną biblioteką, ale rzeczywistością osób duchowych biorących aktywny udział w stwarzaniu świata. Można powiedzieć, że Platon posługuje się „personifikacjami” w opisie Stwórcy w naturalnym odruchu pobożności, niezależnie od tego, że łacińskie pojęcie persona, wywiedzione z greckiego prosophon upowszechniło się dopiero po Boecjuszu. Banalizowanie ${ }^{4}$ genialnego

4 Niektóre karykaturalne interpretacje jego ontologii mogą być efektem tego, że sam Platon posługuje się ironią w Timajosie. Tekst zawiera dwa opisy stwarzania; opowieść „kosmologiczną” (26c-47e), która jest prawdopodobnie żartem z filozofii Pitagorejczyków 
Platońskiego opisu stwarzania było znamiennym procesem w tradycji filozofii zachodniej. Zinterpretowano Platońską Chorę jako „materię pierwszą", następnie uznano, że termin Rzemieślnik (Demiourgous) nie odnosi się do samego Boga, tylko jakiegoś Wykonawcy, by w końcu zinterpretować opis odnoszący się do ontologii stwarzania jako rodzaj jednorazowych zleconych „czynności garncarskich”. Przede wszystkim jednak - przez wyłączenie Chory jako Macierzy z Platońskiej „Trójcy” (Ojciec-dawca form, Odwiecznie rodzone Dziecko i rodząca Macierz) - doprowadzono do obrazu bezsilnego i „bezdusznego” Boga, czystego intelektu, samo-myślącej się myśli, pozbawionej czucia. Ma to związek z przedstawionym niżej opisem Arystotelesowskiego pojmowania duszy wegetatywnej, której funkcje stają się „czysto mechaniczne” (oderwane od czucia). Podobnie jak Arystotelesowska dusza, Bóg Arystotelesowski pozbawiony zostaje tego, co u Platona jest nośnikiem życia - Macierz staje się materią pierwszą (trudno o bardziej dosadne wyrażenie istoty tego procesu „dekonstrukcji” filozoficznej).

Whitehead zdaje sobie sprawę z wartości pojęcia „chora” rozumianego jako jedność osobowa, zarówno w odniesieniu do ludzi jak i innych bytów w przyrodzie o strukturze osobowej. W Przygodach idei, napisanych pięć lat po Process and Reality uznaje, że Platoński opis właściwości chory w Timajosie jest znakomitym przykładem opisu „tożsamości osobowej, pozbawionego szczegółów ludzkiej natury”. Parafrazuje fragment Timajosa, zastępując termin "chora” terminem „tożsamość osobowa”: „tożsamość osobowa jest rzeczą, która przyjmuje wszystkie zdarzenia ludzkiego istnienia (...). Stanowi jakby naturalną macierz wszystkich poruszeń życia. (...) To jego koncepcja podłoża (bypodoche) lub miejsca (chora), którego jedyną funkcją

i opowieść „ontologiczną”(48a-53b), która zawiera poglądy samego Platona Por. Z. Król, Platon i podstawy matematyki współczesnej, Nowa Wieś 2005, 87 oraz K.M. Sayre, Plato's late ontology, Princeton 1983. 
jest narzucanie jedności zdarzeniom składającym się na przyrodę"”. Whitehead pomimo często wyrażanego sprzeciwu wobec Arystotelesowskiego substancjalizmu interpretuje Platońskie pojęcie „chora” po Arystotelesowsku. Nie zauważa, że u Platona Chora stanowi o jedności osobowej wszystkich bytów (nie tylko „bytów w przyrodzie"), nie wyłączając żadnej z osób duchowych ${ }^{6}$, w szczególności Boga, i nie zauważa, że to wspomniana „Platońska Trójca” jako Jedno stanowi najdoskonalszy Prawzór osobowej jedności.

\section{ETAPY ŻYCIA LUDZKIEGO. DZIECIŃSTWO}

Każdy z wyżej wymienionych etapów ma swój okres wczesny, środkowy i późny. W przypadku dzieciństwa pierwszym przełomowym momentem jest tak zwana rewolucja czterolatka. Okres środkowy dzieciństwa trwa od tego momentu do początku okresu dojrzewania, tj. do około 13-14 roku życia, kiedy rozpoczyna się ostatnia faza dzieciństwa, będąca jednocześnie wchodzeniem w etap dorosłości. W okresie wczesnego dzieciństwa dziecko integruje swoja osobowość poprzez ruch i emocje bez udziału mowy artykułowanej. Niemowlę posługuje się ciałem jako narzędziem odbierania, przeżywania i wywoływania emocji. Treści, jakimi posługuje się umysł dziecka, nie są pojęciowymi reprezentacjami, lecz ucieleśnionymi emocjami, których najistotniejszym kontekstem jest bezpośrednio odczuwana więź z opiekunami. Psychoanalitycy określają ten stan umysłu - poprzedzający ukształtowanie się ,ja społecznego”- jako „sen o wszechogarniającej opiece". Jest to jednak, jak wskazują takie zjawiska jak np. „zespół przeżuwania”, stan afektywnej samodzielności

5 A.N. Whitehead, Przygody idei, tłum z ang. M. Piwowarczyk, Warszawa 2020, 224-225.

6 „To, co nie mieści się [nie jest objęte przez Chorę] ani na Ziemi, ani gdzieś w Niebie, jest niczym". Por. Platon, Timajos, dz. cyt. 67.

7 Zespół przeżuwania to zaburzenie funkcji przyjmowania i absorpcji pożywienia u niemowląt na tle psychicznym (diagnozuje się je, gdy brak somatycznych przyczyn zaburzenia). Występuje wówczas, gdy niemowlę nie ma zaspokojonej podstawowej potrzeby więzi 
i kreatywności. Jagna Brudzińska nawiązując do późnych prac Edmunda Husserla wprowadza pojęcie „fantazji cielesnej”, aby opisać ten rodzaj „intencjonalności”, którym posługują się niemowlęta. Platon mówi o „doznawaniu na sposób pożądania” (meta epithymia) pisząc o duszy pożądliwej (epithymetikon), która jest w jego koncepcji ośrodkiem czucia i doznawania afektów. Jest to jednak (w dużej mierze za sprawą Arystotelesa) chyba najczęściej błędnie interpretowany aspekt Platońskiej psychologii. Przejawia się on najsilniej $\mathrm{w}$ pierwszym etapie rozwoju osoby $\mathrm{i}$ jest niezwykle istotny z punktu widzenia terapeutycznego.

Niemowlę jest od urodzenia osobą pośród innych osób. Pomimo swej niesamodzielności fizycznej, tj. pełnej zależności od opieki dorosłych w kwestiach związanych z przetrwaniem, jest już, jak powiada Colwyn Trevarthen', samodzielnym i twórczym uczestnikiem kultury oraz podmiotem w relacjach interpersonalnych. Rodzimy się z umiejętnością rozpoznawania intencji oraz emocji innych ludzi, a także gotowością działania we wspólnej przestrzeni znaczeń. Niemowlęta, gdy zaspokojona jest ich podstawowa potrzeba więzi, ujawniają gotowość do zabawy z innymi ludźmi, której swoboda i kreatywność przekracza dalece możliwości innych naczelnych. Noworodek jest od początku wrażliwy na obecność innych osób i prowadzi z nimi swoiste negocjacje, których efektem w kolejnych miesiącach jest wytworzenie rytuałów, będących jego sposobem

osobowej. Występuje najczęściej u niemowląt wychowujących się bez matki. Włoski psychoanalityk Eugenio Gaddini zauważył, że dzieci mogą w ten sposób prowokować stan psychicznego spełnienia. Po długim okresie „przeżuwania” połknięcie pokarmu wywoływało u niemowląt odczucie błogostanu. Por. J. Brudzińska, Imitation and Individuation. Social Imaginaries 5(2019)1, 81-95.

8 J. Brudzińska, Becoming a person in the life-world, Paradigmi. Rivista di critica filosofica 3(2014), 91-110.

9 Por. C. Trevarthen, How is it like to be a person who knows nothing? Defining the Active Intersubjective Mind of w newborn Human Being, Infant and Child Development (2010), online Wiley publishers https://www.slideshare.net/SDRTL/what-is-it-like-to-be-a-person-who-knows-nothing, dostęp: 2.02.2020. 
uczestniczenia w kulturze. Zachowania te nie zostawiają wątpliwości co do osobowego sposobu bycia niemowląt. Jak to pokazują badania Trevarthena, noworodki dostosowują rytm ruchu swojego ciała do rytmu ruchu innych ludzi, w taki sposób, który można uznać za przejaw zdolności wyczuwania emocji oraz zamiarów ${ }^{10}$ (oprócz obserwacji zachowania potwierdzają to też wyniki badań neurologicznych, m.in. neuronów lustrzanych). Niemal od razu po urodzeniu ujawnia się u niemowląt trwała dyspozycja do tworzenia emocjonalnej więzi z innymi osobami, która jest podstawą rozwoju naszej kulturowej inteligencji. Urodziliśmy się, jak powiada Trevarthen, aby przeżywać różne stany, dawać im wyraz, wzbudzać zainteresowanie nimi $\mathrm{u}$ innych oraz wywoływać emocjonalne reakcje na nasze przeżycia u innych ludzi. Jego zdaniem, badania nad zachowaniem niemowląt, jeśli tylko społeczność naukowa uświadomi sobie ich znaczenie, powinny doprowadzić do powstania nowej psychologii, opartej na idei kreatywności i wspólnotowości ludzkiego poznania ${ }^{11}$. Nasze stawanie się osobą we wczesnym dzieciństwie nie polega na przechodzeniu z jakiegoś nieświadomego, „czysto zwierzęcego”, całkowicie bezosobowego poziomu bycia na poziom osobowy. Opanowanie języka czy zdolność świadomego myślenia pojęciowego nie są warunkami koniecznymi naszego przeżywania relacji osobowych. Odwrotnie, zdolności językowe mogą rozwinąć się w człowieku jedynie na bazie bardziej pierwotnych umiejętności nawiązywania relacji z innymi ludźmi.

Odróżnienie relacji, jakie osoby ludzkie nawiązują na poziomie czującego ciała, od relacji na poziomie umysłu pojęciowego jest przydatne nie tylko w kontekście ogólnych teorii rozwoju osobowego. Jest podstawą nowoczesnego podejścia do autyzmu dziecięcego, dającego

10 Trevarthen podaje przykład trzymiesięcznego niemowlęcia, które lewą ręką porusza w rytm (dość skomplikowany) kołysanki śpiewanej przez matkę z około półsekundowym wyprzedzeniem. Czyni to w taki sposób, że profesjonalny dyrygent poproszony o analizę tego zdarzenia uznaje to za doskonały przykład dyrygentury.

11 Por. tamże, 7-8. 
nadzieję na opracowanie doskonalszych metod terapeutycznych. Shaun Gallagher ${ }^{12}$ podejmuje krytykę klasycznego modelu poznawczego w badaniach autyzmu tzw. teorii teorii (theory-theory approach). W modelu tym istotą autyzmu jest niezdolność brania pod uwagę stanów mentalnych innych osób. Głównym argumentem za tym podejściem były badania dzieci „testem fałszywego przekonania” 13 . Dzieci ze zdiagnozowanym autyzmem, w przeciwieństwie do innych dzieci, odpowiadają na pytania tak, jakby ich własna perspektywa poznawcza była jedyną - nie biorą pod uwagę zmian stanów mentalnych innych osób. Według Gallaghera model umysłu, na jakim opiera się teoria teorii, choć zgodny z paradygmatem poznawczym pokaźnej części współczesnej kognitywistyki, jest błędny.

Stawanie się osobą w okresie tzw. rewolucji czterolatka nie polega na uzyskaniu czysto kognitywnych kompetencji (powstanie reprezentacji stanów umysłowych), lecz jest wynikiem ewolucji umiejętności interpersonalnych, w szczególności rozwoju kompetencji w obszarze tzw. intersubiektywności wtórnej, która musi nadbudować się na pierwotnej (emocjonalno-ruchowej) intersubiektywności rozwijającej się już od momentu urodzin. Istotą autyzmu nie jest brak określonych „reprezentacji umysłowych”, lecz zaburzenie interakcji społecznych, które ma swoje źródło w problemach związanych z łączeniem ruchu, percepcji i wspomnianego wyżej rezonansu emocjonalnego. Dopiero pojmowanie rozwoju umysłowego w paradygmacie dynamicznym, tj. pojmowanie umysłu niemowlęcia jako podmiotu aktywnie czującego i osadzenie myślenia na fundamencie emocjonalnym i praktycznym

12 S. Gallagher, Understanding Interpersonal Problems in Autism: Interaction Theory as An Alternative to Theory of Mind, https://www.researchgate.net/publicatio, dostęp 6.05.2020.

13 Test polega na tym, że jedna osoba chowa przedmiot w miejscu A, odchodzi, a druga przekłada go w miejsce B i także odchodzi. Kiedy wraca pierwsza osoba, zadajemy badanemu dziecku pytanie: „Gdzie pierwsza osoba poszuka przedmiotu?” M. Białecka-Pikul, Krytycznie o sposobach badania teorii umysłu. Dziecięce strategie radzenia sobie z rozumieniem stanów mentalnych na materiale metafor, Psychologia Rozwojowa 12(2007)1, 23-36. 
związanym z umiejętnością rozumienia emocji oraz intencji innych ludzi, tłumaczy nie tylko deficyty poznawcze, ale też charakterystyczne zachowania autystyków, takie jak upodobanie do powtarzania określonych czynności, perseweracje i echolalie, nietypowe powtarzalne sposoby poruszania się oraz nadmierną reaktywność.

Podsumowując, istotną kwestią z punktu widzenia filozoficznego jest rozumienie człowieka w okresie wczesnego dzieciństwa jako osoby. Przydatne do tego celu jest pojęcie czucia ciała i afektów cielesnych, tak jak jest ono rozumiane $\mathrm{w}$ psychoanalizie genetycznej Jagny Brudzińskiej, ale też w Platońskiej psychologii. Pojęcie „umysłu ukrytego" charakterystyczne dla modeli wejście-wyjście (Input-Output) lub „modeli kanapkowych” we współczesnej kognitywistyce ma sens dopiero $\mathrm{w}$ odniesieniu do struktur myślenia pojęciowego, które powstają w późniejszym okresie rozwoju. Błędem jest traktowanie umysłu małego dziecka jako „wewnętrznego przetwornika danych”, tajemniczego „procesora” ukrytego w mózgu i nadającego znaczenie poruszeniom ciała. Procesy „myślenia ciałem” jakie zachodzą we wczesnym dzieciństwie są w nas bazą i tłem dla myślenia pojęciowego.

\section{WCHODZENIE W DOROSŁOŚĆ. BUDOWANIE SAMODZIELNOŚCI}

Dzieciństwo biologiczne w naszym kręgu kulturowym trwa do ok. 13-15 roku życia (u dziewcząt krócej niż u chłopców). Jego koniec znamionują wyraźne zmiany budowy fizycznej - nie tylko dojrzewanie płciowe, ale też znaczące zmiany w sposobie funkcjonowania i budowie mózgu. Nadal następuje ,wielkie wymieranie” neuronów, które rozpoczyna się już od urodzenia i trwa do około 17 roku życia, przede wszystkim jednak następuje wzmacnianie niektórych połączeń i mielinizacja neuronów. Charakterystyczną cechą tego etapu rozwoju mózgu jest intensywna przebudowa w obszarach podkorowych i brak rozwoju w korze nowej. Obrazowo ujmuje to Marek Kaczmarczyk: „Nowe obszary, w tym sama kora mózgowa wydają się zwlekać, jakby 
czekały na powstanie fizjologicznej bazy, pewnego oparcia na sprawdzonym podłożu, utrwalonym w odległej przeszłości. W krytycznym momencie nastolatek obdarzony jest w pełni dojrzałymi strukturami podkorowymi i niedojrzałą korą mózgową, niezdolną do przejęcia pełnej kontroli"14. Mózg nie przestaje się rozwijać przez cały okres dorosłości, pełną sprawność uzyskuje dopiero w momencie kiedy wchodzimy w okres nazwany tu przeze mnie dojrzałością, czyli po 40 roku życia. Dopiero wówczas mózg może w pełni wykorzystać potencjał kory przedczołowej, gdzie znajdują się ośrodki naszego racjonalnego myślenia i skąd, używając Platońskiej formuły, może on ,jak ze szczytu cytadeli” wysyłać skuteczne dyspozycje dla całego organizmu. U nastolatków kora czołowa i przedczołowa nie są jeszcze w pełni rozwinięte. Trwa również budowa połączeń pomiędzy tymi strukturami a częścią limbiczną. Mózg w tej fazie rozwoju jest szczególnie wrażliwy na działanie tzw. „układu nagrody”, czyli połączeń, które powodują wytwarzanie w korze czołowej opioidów endogennych wywołujących uczucie przyjemności. Czynności prowadzące do wytwarzania tych związków chemicznych domagają się powtarzania, czyniąc mózg młodego człowieka szczególnie podatnym na uzależnienia.

Powyższych uwag na temat rozwoju mózgu nie należy interpretować deterministycznie np. jako uzasadnienia permisywizmu w podejściu do poszukiwania przyjemności przez nastolatków. Wręcz przeciwnie, badania te ukazują mózg jako twór niezwykle plastyczny. Dokonywanie określonych wyborów, działanie pod wpływem określonego typu odczuć powoduje zmiany w budowie mózgu, który wzmacnia połączenia często używane. Mózg dostosowuje się do osoby, a nie osoba do swojego mózgu! Kieruje to naszą uwagę w stronę mechanizmów społecznych i jest kolejnym argumentem na rzecz prymatu sfery duchowej wobec fizycznej.

14 M. Kaczmarczyk, Szkoła neuronów. O nastolatkach, kompromisach i wychowaniu, Słupsk 2018, 68. 
W społeczeństwach cywilizacji zachodniej młody człowiek zmuszony jest na tym wczesnym etapie rozwoju swojego mózgu stawiać sobie pytania o swoją drogę życiową (pojawiają się długoterminowe plany), dokonywać istotnych dla swojego życia wyborów (np. wybór szkoły, związany z przyszłym zawodem). Adolescencja jest czasem „przełomu”, przejścia od sposobu funkcjonowania, w którym zależymy w pełni od rodziców do funkcjonowania autonomicznego. Od strony psychologicznej oznacza to, że jednostka nie może już przeżywać uczuć i wartości rodziców jako własnych, lecz staje się podmiotem samodzielnym, zdolnym wchodzić w związki z innymi osobami i podejmować długoterminowe zobowiązania. Bunt nastolatków jest symbolem tego procesu, który ma prowadzić do rozwoju niezależnej osobowości. Od strony pozytywnej oznacza to zdolność uświadomienia sobie swojej odrębności, przede wszystkim niezależności od świata uczuć i wartości rodzicielskich. Gordon Allport mówi o pojawieniu się w tej fazie życia "dążeń propriacyjnych" - długoterminowych dążeń (proprium to w tym ujęciu pierwotne centrum osobowe), które nie mają charakteru afektywnego, lecz są wynikiem wglądu w wartości.

Dorosłość ${ }^{15}$ polega na samodzielnym pełnieniu ról społecznych, co oznacza umiejętność samodzielnego podejmowania decyzji, odpowiedzialność moralną i prawną, a także zdolność podejmowania długoterminowych zobowiązań. Warto zwrócić uwagę na kontrast pomiędzy biologicznym uposażeniem młodego człowieka a wymogami, jakie nakłada na niego społeczeństwo. Nie pozostawia to złudzeń, że dojrzali członkowie społeczeństwa muszą stworzyć warunki umożliwiające młodym ludziom wejście w świat odpowiedzialności. Kultury pierwotne posiadały szereg obrzędów inicjacyjnych, które pozwalały przeżywać świadomie trudny etap przejścia od dzieciństwa

15 Zdolność do samodzielnego pełnienia ról społecznych nazywa się niekiedy dojrzałością, ja używam tu pojęcia dorosłość, termin dojrzałość rezerwując dla okresu niżej opisanego. 
do dorosłości. Obrzęd przekazania czuringów ${ }^{16} \mathrm{w}$ społeczeństwie Aborygenów w Australii służył symbolicznemu przekazaniu siły Przodków. Czuringi - kamienie symbolizujące moc plemienia i przekazywane w momencie inicjacji - miały moc podwójną: odwoływały się do ambicji, ale też głębiej zakorzenionych uczuć swojskości i więzi rodzicielskiej pozwalających zachować pogodę ducha również w chwilach zagrożenia. Wydaje się, że intencją Jezusa w modlitwie Pańskiej (Ojcze nasz) jest nawiązanie do tej podstawowej potrzeby, ale już bez plemiennego partykularyzmu, choć w formule modlitwy wspólnotowej - podmiotem w tej modlitwie nie jest ,ja”, lecz „my” pojmowane jako najbliższa społeczność.

Potrzeba samorzutności, posiadania osobistych dążeń i pragnienie doświadczania wolności, jaka jest naturalną cechą człowieka w okresie dorastania, nie może być traktowana jako wyznacznik człowieczeństwa. Wydaje się, że egzystencjalizm, począwszy od Fryderyka Nietzschego, akcentuje tę właśnie fazę (warto przypomnieć, że faza dopełniająca, która w przyjętym tu modelu jest odpowiednikiem etapu dorosłości, cechuje się akcentowaniem właśnie tego wymiaru bycia ludzkiego). Aby móc doświadczać wolności człowiek potrzebuje jednak punktów odniesienia w postaci struktury zastanej. Problemem współczesnego człowieka Zachodu jest nadmiar możliwości, a nie ich brak. Podkreślanie mnogości celów, a przy tym egzystencjalna pustka w świecie „osób dojrzałych”, brak okazji do wykazania osobistej odpowiedzialności, za to wiele okazji do „życia na kredyt”, niedostatek wzorców osobowych, za to bogactwo ofert krótkotrwałego zadowolenia. Ogromna przestrzeń osobistego wyboru i brak podstaw, na których można ten wybór oprzeć. Wartości etyczne wydają się zawieszone w ontycznej próżni. Przyjęcie ich lub odrzucenie jawi się jako decyzja o ogromnym znaczeniu, a jednocześnie

16 M. Eliade, Historia wierzeń i idei religijnych, t. 1, tłum. z ang. S. Tokarski, Warszawa 1988, 23. 
jednostka doświadcza poczucia braku kompetencji intelektualnych i osobowościowych, aby ją podjąć.

\section{DOJRZAŁA OSOBA LUDZKA}

W pierwszych etapach życia następuje kształtowanie struktury odrębnego „ja”, które w końcu zyskuje autonomię i wolność pozwalającą $\mathrm{mu} \mathrm{w}$ pełni oddać siebie innym osobom. Człowiek w dzieciństwie uczy się ujmować siebie jako niezależny podmiot, najpierw jako odrębny byt fizyczny, zdolny do samodzielnego ruchu, a w końcu jako osobę zdolną podejmować samodzielne decyzje i świadomie pełniącą określone role społeczne. Po przełomie w okresie dorastania i względnej stabilności w okresie dorosłości kolejnym przełomem jest tzw. kryzys wieku średniego. W okresie około 40-50 roku życia ludzie często skarżą się na poczucie wypalenia zawodowego lub doświadczają poczucia pustki, nawet pomimo sukcesu zawodowego. Często pojawiają się w tym okresie kryzysy w związkach. Jest to okres przełomu, rzadko kiedy świadomie przeżywany jako etap dojrzewania. Przyzwyczajony do rozwiązywania problemów w świecie zewnętrznym dorosły człowiek, nie zauważa, że to on sam jest problemem. Przyzwyczajony, by realizować ambicje własne, nie zauważa, że jest zapraszany, by przejść przemianę strukturalną. Noetyczna dusza ludzka domaga się teraz pełni swoich praw. Na etapie dojrzałości osoba zaczyna uświadamiać sobie wyraźnie (dopiero teraz ma do tego predyspozycje intelektualne) to, co wcześniej jedynie przeczuwała, że „królestwo jej nie jest $\mathrm{z}$ tego świata”.

Greckie słowo basileion, użyte w sparafrazowanym tu znanym fragmencie Ewangelii jest terminem stosowanym przez Platona, by opisać ten stan ducha, który osoba osiąga, kiedy zdolna jest do rozumnego królowania (basileuon auton), to znaczy, kiedy jej państwo wewnętrzne realizuje ideał sprawiedliwości. Kreśląc obraz człowieka realizującego w największym możliwym stopniu taki ideał, Platon (niemal jak Izajasz w pieśni sługi Bożego), przedstawia wizję 
człowieka prostego i szlachetnego, który „choć nikomu krzywdy nie wyrządził, ma opinię najgorszą, aby jego sprawiedliwość była wystawiona na próbę (...) idzie prosto aż do śmierci (...) będzie biczowany, torturowany, więziony i oczy mu wypalą, a w końcu wszelkie zło wycierpiawszy na pal zostanie wbity"17. Potrzeba perspektywy drugiej połowy życia, aby uchwycić sens tej wizji. Platońskie Państwo otwiera przemowa prostodusznego staruszka Kefalosa, który tak chwali zalety wieku dojrzałego: „im bardziej więdną inne przyjemności cielesne, tym bardziej rosną rozkosze związane $\mathrm{z}$ inteligentną rozmową (...), jak człowieka zaczynają nachodzić myśli o śmierci, wtedy się w serce zaczyna wkradać obawa i troska o rzeczy, o które się człowiek przedtem nie troszczył i nie obawiał (...) te bajki o tym, co się dzieje w Hadesie, że ten, co tu ludziom krzywdę robił, musi tam pokutować, człowiek się dotąd $z$ tych rzeczy śmiał, a teraz one mu duszę zawracają"18.

Pierwsza księga Państwa to konfrontacja dwu postaw człowieka wobec życia, tej dorosłej - praktycznej, ukierunkowanej na wymierny sukces osobisty i uznanie społeczne, charakterystycznej dla pierwszej połowy życia, reprezentowanej tu przez Trazymacha oraz tej dojrzałej - skoncentrowanej na relacjach osobowych, reprezentowanej przez Sokratesa. Po mistrzowsku Platon ukazuje tu niewspółmierność obu tych postaw, którą Jung wyraża dosadną metaforą: to, co rano było wielkie, wieczorem staje się małe, a to, co rano było prawdą, wieczorem staje się kłamstwem. Inna Jungowska metafora - cienia i persony - pozwala od strony psychoanalitycznej uchwycić różnicę pomiędzy osobą dorosłą a dojrzałą. W procesie socjalizacji osoba uczy się mechanizmów obronnych, takich jak wyparcie, projekcja czy racjonalizacje, które pozwalają zachować pozytywny stan emocji kosztem poczucia rzeczywistości. Persona jest tym, co przyjemnie jest nam w sobie widzieć, tym, co odsłaniamy światu, aspekty

17 Platon, Państwo, tłum. z gr. W. Witwicki, Kęty 1999, 53-54 (361b-362a).

18 Tamże, 14, 18 (328d, 330d). 
nieprzyjemne naszego świata zasnuwając cieniem. Charakterystyczne dla etapu persony są radykalne osądy, oparte na szybkich reakcjach emocjonalnych. Tzw. dorosły formułuje zdecydowane osądy pozwalające mu skutecznie działać w rzeczywistości społecznej. Typowa dla osób w drugiej połowie życia jest skłonność dostrzegania pozytywnych aspektów również tego, co dotąd nawykowo traktowali jako „ciemną stronę”.

Ostatnia część Państwa to znów nawiązanie do Hadesu i opis sądu nad duszą po śmierci. „Królestwo”, które opisuje Platon w Państwie, jest bardziej zaproszeniem do dojrzałości niż propozycją konkretnego rozwiązania politycznego (odpowiedzią na takie zapotrzebowanie wydają się raczej Platońskie Prawa). Jest w tym dialogu wiele wątków autobiograficznych: bracia Platona jako rozmówcy, nawiązania do surowego stylu wychowania przez ostrą w słowach matkę i ustępliwego ojca, analizy różnych typów ludzkich, rozważania nad różnymi stylami wychowania oraz ich wpływem na osobowość, w końcu barwny opis duchowej inicjacji, czy duchowego dojrzewania w postaci metafory jaskini. Warto pamiętać, że dialog ten pisze osoba, która próbowała już konkretnie i bezpośrednio wpłynąć na kształt polityki w Syrakuzach. Teraz zdaje sobie sprawę, że realny wpływ na państwo ma osobiste nawrócenie i propagowanie (głównie w kręgu przyjaciól) postawy, która reformy świata zawsze zaczyna od siebie. Richard Rohr, w swojej książce o duchowości drugiej połowy życia, nawiązuje do Platońskiej idei odsłaniania niepamięci: „Wszyscy cierpimy z powodu błędnej tożsamości. Życie polega na stawaniu się w pełni i świadomie tym, kim jesteśmy, jednak zazwyczaj nie znamy swojego »ja«. To tak jakbyśmy wszyscy zapadli na absolutna amnezję. (...) Ojcowie Kościoła wschodniego nigdy nie zapomnieli o tym, co nazwali teozą lub przebóstwieniem (...), mimo to pamięć Ojców Kościoła stała się częścią niepamięci Zachodu”"19. Dojrzałość

19 R. Rohr, Spadać w górę. Duchowość na obie połowy życia, tłum. z ang. B. Majczyna, Kraków 2017, 141-142. 
to czas rozumienia i przypominania sobie, co Platon obrazuje swojej metaforze jaskini. Nie sposób dostrzec prawdy o sobie będąc bez reszty zaangażowanym w sprawy „tego świata”. Dojrzałość to czas zmieniania perspektywy.

O ile bycie dorosłą osobą ludzką przejawia się przede wszystkim poprzez akty podejmowania decyzji, dokonywanie wyborów, o tyle dojrzałość głównie poprzez pogłębienie relacji osobowych - przeżywanie trwałych dyspozycji uczuciowych, dojrzałą miłość oraz zdrowy dystans wobec krótkotrwałych poruszeń emocjonalnych. Platon opisuje (w Fajdrosie) dojrzałą miłość jako stan duszy, w której instynktowne pożądania - emocje pasywne (pate) - podporządkowane zostają emocjom aktywnym (thymou) pod kierunkiem „zauroczonego Pięknem" intelektu (nous). Na pierwszy rzut oka może się to wydać propozycją jakiejś narcystycznej ucieczki w świat własnych przeżyć estetycznych. W świecie Platona nie ma jednak bytów osobnych. Słowo „Piękno” jest tu nazwą jednostkową bytu, którego inną nazwą jest „Dobro”, a także „Jedno”. Ten byt w Timajosie jest porównany do trzyosobowej rodziny, w której Ten, który zawsze jest i odwiecznie rodzi, jest Ojcem, To, które odwiecznie powstaje, jest Dzieckiem, a Ta, w której wszystko się rodzi - Matką. W Państwie taka „rodzinna” harmonia zmysłowych i intelektualnych aspektów psychiki cechuje człowieka sprawiedliwego (dikaios), czyli etycznie dobrego (agatos), który będąc dobry wewnętrznie musi okazać się dobry w relacjach z innymi - tych dwu aspektów nie da się u Platona rozdzielić.

\section{UCZUCIA DUCHOWE I EMOCJE CIAŁA. NIEŚWIADOME WYMIARY OSOBY LUDZKIEJ W UJĘCIU PLATONA}

Należy podkreślić rolę emocji cielesnych (pate, tymou) w kształtowaniu dojrzałej osobowości. Ucieleśnienie jest często pomijanym aspektem Platońskiej psychologii. Ma to związek z mieszaniem cielesności z materialnością oraz niewłaściwym interpretowaniem metafory „wyzwalanie się z więzów ciała”. Myli się etyczne znaczenie 
tej metafory $\mathrm{z}$ odrzucaniem cielesności jako elementu struktury psychicznej człowieka. Afekty według Platona należy wychować (głównie przez łagodną perswazję) - nie da się ich „odrzucić”. Aby wychować afekty, trzeba je dostrzegać i szanować ich autonomię. Negatywnej ocenie moralnej podlega wybór folgowania sobie i swoim instynktownym osądom, a nie ich emotywne źródło. Traktowanie afektów jak elementów racjonalnych, podległych woli i bezpośredniej ocenie sprzyja mechanizmom wyparcia i zaprzeczenia, które w końcu prowadzą do całkowitego „zacienienia” prawdziwej rzeczywistości.

Uważa się często, że Platon jest dualistą w podobnym sensie jak Kartezjusz, a Arystotelesowi przypisuje się stanowisko pośrednie. Tymczasem już u Arystotelesa rozpoczyna się proces odrywania emocji od ich cielesnego ugruntowania oraz ich „intelektualizowanie”. Dusza według Arystotelesa podobnie jak u Platona dzieli się na część rozumną (logistikon) i nierozumną (alogistikon), jednak część nierozumną dzieli on inaczej niż Platon. U Platona część niższa duszy nierozumnej to dziedzina afektów i pożądań (epithymetikon), która jak Arystotelesowska nie uczestniczy w rozumie, jednak odbiera wrażenia zmysłowe i jest źródłem pożądań zmysłowych. Arystoteles niższej duszy zmysłowej przypisuje jedynie funkcje wegetatywne ( $f-$ tykon, freptikos), natomiast funkcje pożądania (epithymia) i pragnienia (orektikos) wraz z doznawaniem wrażeń (aistesis) umieszcza w wyższej, uczestniczącej w rozumie duszy zmysłowej. W ten sposób najniższa dusza przestaje być nieświadomym (niedostępnym racjonalnej kontroli) centrum czucia a pożądania (epithymia) nabierają bardziej umysłowego charakteru. To, co u Platona stanowi o cielesności człowieka - jego wymiar afektywny - zostaje u Arystotelesa sprowadzone do funkcji rośnięcia i rozmnażania oderwanego od wrażeń zmysłowych. Stąd tylko krok do Kartezjańskiej koncepcji „ducha w maszynie”.

Problem rozumienia natury emocji cielesnych czy pożądań naturalnych jest $\mathrm{z}$ punktu widzenia kwestii dojrzałości niezwykle istotny, a zarazem trudny do uchwycenia. Emocje cielesne w czystej, pozbawionej myślenia i pojęć postaci przejawiają się w ludzkim 
bezpośrednim doświadczeniu jedynie w dzieciństwie. Dorośli ludzie pożądają poprzez swoje myśli i wyobrażenia. Nasza miłość zmysłowa $\mathrm{w}$ dorosłości jest przeżywana w obszarze znaczeń, sensu, odniesień osobowych, towarzyszą jej oczywiście doświadczenia w obszarze fizycznym, ale są one zawsze włączone w obszar kulturowy i zinterpretowane. W wieku dorosłym, aby wyjaśnić sobie znaczenie naszych emocji, potrzebujemy pojęć, symboli i opowieści. Jednak ze swej istoty pozostają one nieuświadomione i autonomiczne. Nasze pierwotne reakcje emocjonalne ukształtowały się w okresie, kiedy nie znaliśmy słów i nadal mają istotny wpływ na nasze życie w tej jego warstwie, która nie jest zdolna posługiwać się mową. „Przemawiają" do nas jedynie poprzez nasze ciało, poprzez sny i zachowania, które nas samych niekiedy zaskakują. One jednak stanowią o naszym najgłębszym poczuciu więzi ze światem i podstawowym poczuciu wspólnoty z innymi ludźmi. Dojrzałość nie może polegać na wyzbyciu się afektów. W dzieciństwie uczymy się mechanizmów kontroli odruchów emocjonalnych, w dorosłości korzystamy z tej umiejętności aby przekształcać świat, dojrzałość powinna być czasem mądrej akceptacji i refleksji nad ich naturą.

Arystotelesowska koncepcja psychiki ludzkiej jest nie tylko bardziej szkolna czy „naukowa”, ale też bardziej deterministyczna niż Platońska. Doskonałość duszy (arete) to wedle Stagiryty trwały nawyk (eksis) dobrego decydowania, który raz ukształtowany jest w zasadzie nieodwracalny. Przypomina efekt złego lub dobrego treningu żołnierskiego. Platońskie nastawienie wyrasta $z$ doświadczenia pedagoga-terapeuty, który chce poprzez filozofię (terapię filozoficzną) leczyć dusze obywateli. Sytuacje „majeutycznych wglądów”, mogą prowadzić do głębokiej zmiany myślenia - „metanoi”, prowadzącej do zmiany w strukturze duszy, która może prowadzić do zmiany nawyków postępowania. Nawyk jest tu efektem zmiany, jaka dokonuje się w duszy, a nie jej przyczyną.

Z kolei wspólną cechą Arystotelesowskiej i Kartezjańskiej koncepcji duszy jest ich racjonalistyczny charakter. Nieracjonalność jest 
u nich pewnego rodzaju dewiacją. U Kartezjusza „zaciemnieniem umysłu” (np. jak „u szaleńców pod wpływem oparów ciemnej żółci”) - u Arystotelesa odstępstwem od rozumnej miary („złotego środka”). Tak rozumiana racjonalność prowadzi do pojęcia samoprzejrzystej duszy. Nie ma w niej miejsca na nieświadomość. U Arystotelesa poza funkcjami wegetatywnymi wszystkie funkcje psychiczne uczestniczą w rozumie. Kartezjański z kolei sposób rozumienia świadomości (cogito) czyni z pojęcia „przeżyć nieświadomych” ideę sprzeczną. W przeciwieństwie do tego, u Platona doznania duszy pożądającej nie uczestniczą wprawdzie w rozumie, ale objawiają się we śnie albo w wizjach poprzez obrazy, które wymagają dopiero racjonalnej interpretacji, ale mogą być nośnikiem istotnych treści. Rozum jednostkowy jest też w filozofii Platona ograniczony „od góry” uczestniczy „wirtualnie” w Rozumie obejmującym całość świata idei - aktualnie doświadcza jednak tylko nieznacznej jego części. Można zatem mówić o dwu rodzajach nieświadomości u Platona. Pierwsza, przypominająca nieco nieświadomość Freudowską, to nieświadomość konkretnych doświadczeń duszy pożądającej, która uczestniczy w Macierzy (Chora), lecz nie w Rozumie i przejawia się w snach oraz wymagających interpretacji wizjach. Druga, podobna do Jungowskiej nieświadomości zbiorowej, polega na uczestniczeniu jednostkowego rozumu w Rozumie. Dialogi Platona ukazują proces stawania się osobą dojrzałą polegający na wkraczaniu jednostki w obszar tego, co dotąd było dla niej nieuświadomione, na rozszerzaniu jej osobistego pola świadomości. Rozmowy Sokratesa w Platońskich dialogach mają poprzez wspólne poszukiwanie definicji istotowych obudzić w jednostce funkcje intelektualne w kontekście jej konkretnej sytuacji życiowej, co w istocie sprowadza się do „procesu stwarzania” czyli „przekonywania” destrukcyjnych odruchów emocjonalnych (nieświadomość indywidualna) jednostki by „posłuchały mądrych rad Rozumu" (nieświadomość zbiorowa). Najczęściej przedmiotem rozmowy jest jedna $\mathrm{z}$ cnót (arete), którą można pojąć od strony 
subiektywnej jako uczucie duchowe tzn. stałą dyspozycję duszy, do poddawania się wplywowi określonego ,archetypu”.

$\mathrm{Na}$ pierwszy rzut oka lekarskie anatomiczne podejście do duszy wegetatywnej Arystotelesa wydaje się bardziej nowoczesne niż „empatyczne” czy „afektywne” skłonne do personalizowania podejście Platona, który duszę pożądliwą porównuje do roślin, jednocześnie przypisując jej afekty i dążenia. Współczesne badania potwierdzają jednak słuszność Platońskich intuicji. Antonio Damasio, badając zagadnienie ewolucji uczuć, pisze, że „czucie i subiektywność są starymi zdolnościami i ich debiut nie zależał od kory mózgowej (...) na długo przed epoką kambryjską organizmy jednokomórkowe potrafily reagować na naruszenie ich integralności obronnymi i stabilizującymi reakcjami fizycznymi i chemicznymi. Reakcje te są w praktyce reakcjami emotywnymi, rodzajami programów działań, które w późniejszym etapie ewolucji mogły być umysłowo reprezentowane jako uczucia" 20 . Co więcej, trafne wydaje się też zlokalizowanie przez Platona naszych „pierwotnych afektów” w części brzusznej: "autonomiczny układ nerwowy - skomplikowana sieć nerwów w naszym przewodzie pokarmowym przypomina te [gąbek i stułbi] stare struktury nerwowe. To jeden z powodów, który skłania mnie do przypuszczenia, że ta część układu nerwowego była pierwszym a nie - jak się powszechnie uważa drugim "mózgiem«"21. Fakt, że nasze pierwotne afekty są powiązane $\mathrm{z}$ działaniem autonomicznego układu nerwowego, związanego z częścią brzuszną, i są względnie niezależne nie tylko w stosunku do kory mózgowej i wyższych funkcji psychicznych, ale nawet wobec centralnego układu nerwowego, jest ważnym argumentem na rzecz Platońskiej teorii duszy.

20 A. Damasio, Dziwny porządek rzeczy, tłum. z ang. A. Jankowski, Poznań 2018, 296.

21 Tamże, 75. 


\section{PODSUMOWANIE}

Stawanie się osobą to proces dwuwymiarowy, dokonuje się jako następstwo zdarzeń w czasie przyrody i jako trwanie w rzeczywistości bytów wiecznych. Zarówno nasza struktura psychiczna jako jedność trzech ośrodków: emotywno-czuciowego (Platońska dusza pożądliwa), racjonalno-wolitywnego (dusza mężna) i intelektualno-uczuciowego (dusza rozumna), jak i etapy życia (dzieciństwo, dorosłość, dojrzałość) są odbiciem struktury trwania, której fazy (konformalna, dopełniająca i spełnienie) z kolei są śladem wewnętrznego życia Boga - odwiecznego wzorca tego, co w ludzkim życiu najdoskonalsze duchowej więzi międzyosobowej. Osoby spełniają siebie oddając siebie w twórczym procesie. To, co jest więzią doskonałości, można porównać do polifonii - każdy z głosów musi wybrzmieć „po swojemu w ramach swojej natury", składając się na całość, która jest jednością w wielości. Spojrzenie procesowe na Platońskie ośrodki psychiczne pozwala dostrzec, że tworzą one system hierarchiczny. Każdy z nich, rozwijając się w czasie, staje się podstawą dla kolejnego. Nie istnieją byty izolowane. Dążenie do istnienia niezależnego, jako odrębnej, samookreślającej się jednostki jest tylko jednym etapem w procesie stawania się człowieka. Na każdym etapie człowiek określa siebie poprzez relacje z innymi ludźmi, ale też poprzez relację do Boga. $\mathrm{Na}$ etapie dzieciństwa w procesie życia poprzez emocje i ciało, na etapie dorosłości przez autonomiczne decyzje i plany, na ostatnim etapie poprzez odnajdywanie sensu.

"Odkryte" tu fazy i etapy procesu istnienia prowadzą do odsłonięcia egzystencjalnej struktury człowieka, która przejawia się w życiu każdego niezależnie od kultury, światopoglądu czy wyznania. Alfred Langle, dystansując się w swojej analizie egzystencjalnej od teizmu Frankla, wyróżnia następujące cztery warunki sensownego życia ${ }^{22}$.

22 A. Langle, Gdy rodzi się pytanie o sens. Praktyczne zastosowanie logoterapii, tłum. z ang. A. Grzegorczyk, A. Szymczak, Warszawa 2016, 48-51. 
Akceptacja swojego miejsca w świecie, akceptacja życia w jego żywym przebiegu (emocjonalna relacja z nim, zgoda na życie). Następnie akceptacja wymiaru indywidualności, bycia tą a nie inną osobą, niepowtarzalną i wyjątkową oraz doświadczenie elementarnego uznania, a w efekcie poczucia własnej wartości. W końcu doświadczenie poczucia sensu życia w postaci „oddania” siebie na rzecz wartości „dla innych", a także dodanie swojego udziału w rozwój przyszłości (np. poprzez wychowanie dzieci czy zawód). Podobieństwo tych „egzystencjalnych wymiarów" do zarysowanych wyżej etapów rozwoju osoby ludzkiej, jak i jej zgodność założeniami Platońskiej psychologii dowodzi zarówno uniwersalności przedstawionej tu wizji jak i jej ścisłego związku z praktyką psycho-terapeutyczną.

\section{BIBLIOGRAFIA}

Białecka-Pikul M., Krytycznie o sposobach badania teorii umystu. Dziecięce strategie radzenia sobie z rozumieniem stanów mentalnych na materiale metafor, Psychologia Rozwojowa 12(2007)1, 23-36.

Cobb J. Jr., Stownik pojęć Whiteheada, tłum. z ang. Ł. Lamża, Copernicus Center Press, Kraków 2016.

Damasio A., Dziwny porządek rzeczy, tłum. z ang. A. Jankowski, Dom Wydawniczy Rebis, Poznań 2018.

Eliade M., Historia wierzeń $i$ idei religijnych, t. 1, tłum. zang. S. Tokarski, Instytut Wydawniczy PAX, Warszawa 1988.

Gallagher S., Understanding Interpersonal Problems in Autism: Interaction Theory as An Alternative to Theory of Mind, https://www.researchgate.net/publicatio, dostęp 20.06.2020.

Hurley S., Consciousness in Action, Harvard University Press, Harward 2002.

Kaczmarczyk M., Szkota neuronów. O nastolatkach, kompromisach $i$ wychowaniu, Dobra Literatura, Slupsk 2018.

Król Z., Platon i podstawy matematyki wspótczesnej, Wydawnictwo Rolewski, Nowa Wieś 2005.

Langle A., Gdy rodzi się pytanie o sens. Praktyczne zastosowanie logoterapii, tłum. z ang. A. Grzegorczyk, A. Szymczak, Wydawnictwo Barbelo, Warszawa 2016. Platon, Państwo, tłum z gr. W. Witwicki, Antyk, Kęty 1999.

Platon, Timajos Kritias albo Atlantyk, tłum. z gr. P. Siwek, PWN, Warszawa 1986. 
Rohr R., Spadaí w górę. Duchowośc na obie polowy życia, tlum. z ang. B. Majczyna, WAM, Kraków 2017.

Sayre M.K., Plato's late ontology, Princeton University Press, Princeton 1983. Świeżawski S., Święty Tomasz na nowo odczytany, W drodze, Poznań 1995. Whitehead A.N., Przygody idei, tłum. z ang. M. Piwowarczyk, PWN, Warszawa 2020.

\title{
THE PROCESS OF BECOMING A PERSON
}

\begin{abstract}
The first three sections of this paper are introductory. Their task is to define basic terms such as corporeality, person, stages, phases, and dimensions of the process of becoming a person. A correct understanding of the concept of God turns out to be of particular importance for understanding the concept of the human person. The thesis about the superiority of Platonic theology over Aristotle's is justified. The following sections discuss the stages of becoming a human being: childhood, adulthood, and maturity. Each of them is presented from a perspective that combines the bodily dimension with spirituality. In the last section I attempt to express some of Plato's psychological intuitions in modern language, focusing in particular on his notion of becoming a mature person through spiritual and psychological development. This tends to show Platonism as the basis of modern therapeutic practice.
\end{abstract}

Keywords: person, stages of development, process, becoming, Plato's psychology

\author{
PIOTR LEŚNIAK \\ piotrlesniak@uni.opole.pl \\ Uniwersytet Opolski, Instytut Historii, Katedra Filozofii \\ ul. Strzelców Bytomskich 2, 45-084 Opole \\ ORCID: 0000-0003-3678-513X
}

DOI: 10.21697/spch.2020.56.2.01 